\title{
小棒製品の寸法測定システム
}

佐藤義治*, 井上哲男**

\section{Profile Inspection System of Small Bar Products}

\author{
Yoshiharu Satoh and Tetsuo Inoue
}

\begin{abstract}
Synopsis
Daido Steel Co., Ltd. installed an automatic continuous inspection and conditioning line for small round bar for the purpose of improving accuracy of quality assurance and efficiency at Chita Plant. The line consists of an automatic products conveyance system and automatic inspection devices.

We developed and installed an automatic profile inspection system in the line. The system measures the diameter, the roundness and the bend of each product, and makes a judgement whether the measured values are fit with the customer's specification.

This system consists of a main frame computer, a mini-computer, a micro-computer and a size measuring device as a hierarchy system. The mini-computer controls measuring conditions, such as position of the measuring device, turning speed of product and etc., for accuracy, and the micro-computer gathers measured values and judges the data.
\end{abstract}

This system has been working successfully since 1987 .

\section{1. 綪}

自動車産業をはじめとする機械・部品の製造メ ーカーにおいては性能向上や製造原価低減のため に，部品加工方法は高度化しその加工精度につい ても簃しさが增している。これに応えるため，素 材である特殊鋼に対する品質ニーズる高度化・多 様化している。

こらしたニーズに対応するため大同特殊鋼侏知 多工場（以下当工場という）に括いては，製鋼・ 压延工程では「ELVACプセズ1), 」，「てきすん プロセズ」を開発してきた。また精整ブロセスに おいては，生産性向上・品質保証精度の向上を目

\footnotetext{
1991年 4 月10日受付

“大同特殊鋼獭知多工場

**大同特殊鋼妹情報システム部
}

的として1987年 1月から小棒丸製品の整備・検查 工程をライン化 (SRIC ライン：Small bar Rolling products Inspection and Conditioning line $\left.e^{4)}\right) し, そ の$ 能力をフルに発揮し,現在順調に稼 働している。

この SRIC ラインでは「てきすんプロセス」で压 延されたフリーサイズの製品の寸法品質保証精度 の向上を目的として，寸法測定システムを開発し， 製品全数の寸法測定を実施し生産性及び品質保証 精度の向上に寄与している。本稿ではこの寸法測 定システムの概要と, 寸法・偏径差・端曲りにつ いての品質保証の方法を述べる。

\section{2. 設 備の概 要}

\section{1 ライン樌成}

当 SRIC ラインは, Fig. 1 に示す工程をローラ 搬送などで直結させてライン化することで仮置 


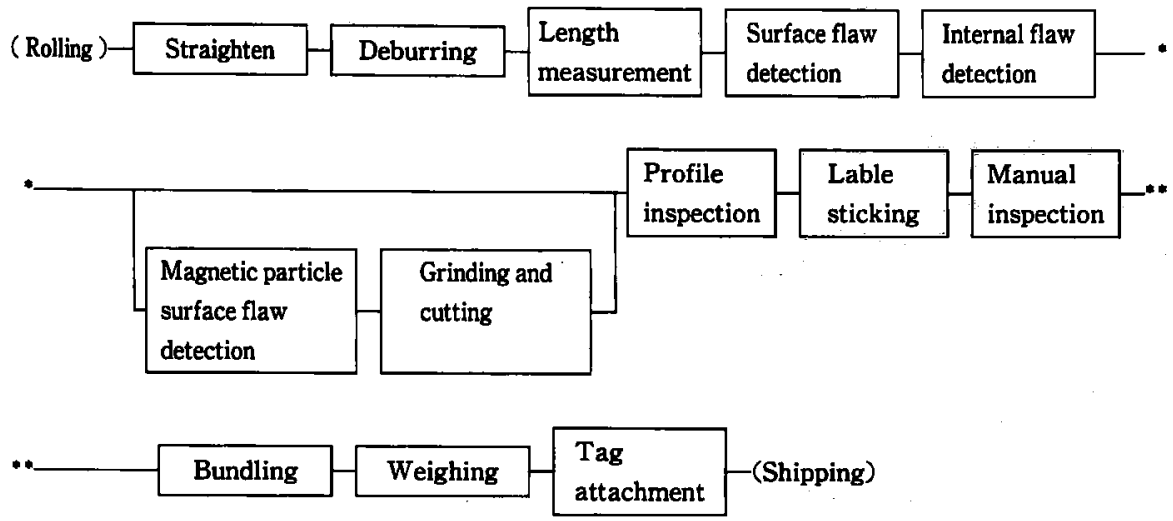

Fig. 1. Process of SRIC.

Table 1. SRIC main equipment.

\begin{tabular}{|c|c|c|}
\hline Main equipment & \multicolumn{2}{|c|}{ Note } \\
\hline Straightener & Two roll type & $120 \mathrm{~m} / \mathrm{min}$ \\
\hline Surface flaw detector & $\begin{array}{l}\text { Magnetic leakage flux flaw } \\
\text { detector }\end{array}$ & $\begin{array}{l}\text { Detection of } 120 \mathrm{~m} / \mathrm{min} \\
\text { excess } 0.15 \mathrm{~mm} \\
\text { depth flaw }\end{array}$ \\
\hline Internal flaw detector & \multirow{2}{*}{\multicolumn{2}{|c|}{$\begin{array}{l}\text { Entire section ultrasonic tester } \\
\text { From } 25 \mathrm{~mm} \text { to } 88 \mathrm{~mm}\end{array}$}} \\
\hline $\begin{array}{l}\text { Size measurement } \\
\text { equipment }\end{array}$ & & \\
\hline $\begin{array}{l}\text { Printer and } \\
\text { sticker of label }\end{array}$ & \multicolumn{2}{|c|}{ Automatic label printing and sticking } \\
\hline
\end{tabular}

き，起重機搬送などのムダ作業を極力排除した整

備・検査ラインである。

また，工程の全体を専用プロコンで制御・管理 し各自動機器にはマイコンを導入するなど FA 技 術を駆使して小人数での稼働を行っている。 以下に SRIC ラインの主な工程を述べる。

- 矯正機：

曲がった製品を魄正して曲がりを除去する。

・端面加工機 :

製品の両端面を切削及びューナー面取りす る。

- MLF (Magnetic leakage flux testing) :

製品の表面症を探偤する。

- US (Ultrasonic testing) :

超音波により製品の内部欠陷を探侮する。

- MG (Magnetic particle testing) :

MLFで廐ありと判定された製品についての 又磁気探傷で目視にて探偤する。またUSで 久陥ありと判定された製品については確認探
傷を行っている。

・疵取り：

MG にて疵ありと判定された製品について疵 取りまたは切断する。

- 寸法測定機 :

製品 1 本ごとに外径寸法, 偏径差, 端曲がり を測定し検査する。

・自動ラベル貼付機：

端面にラベルを自動貼付する。

・出荷検査：

作業者による最終目視検查を行う。

- 結束：

束単位に客先の要求にしたがって番線結束す る。

- 計重：

束単位に質量を計量するこれが出荷質量にな る。

- 入庫：

外観桧查完了分の現品入庫で内質検查と併せ 


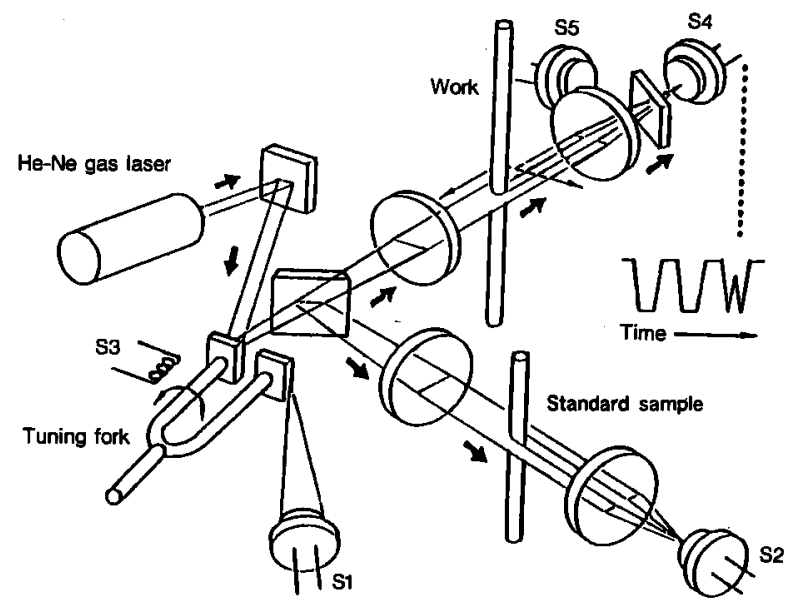

Fig. 2. The principle of optical system of size gauge device ${ }^{\text {s) }}$.

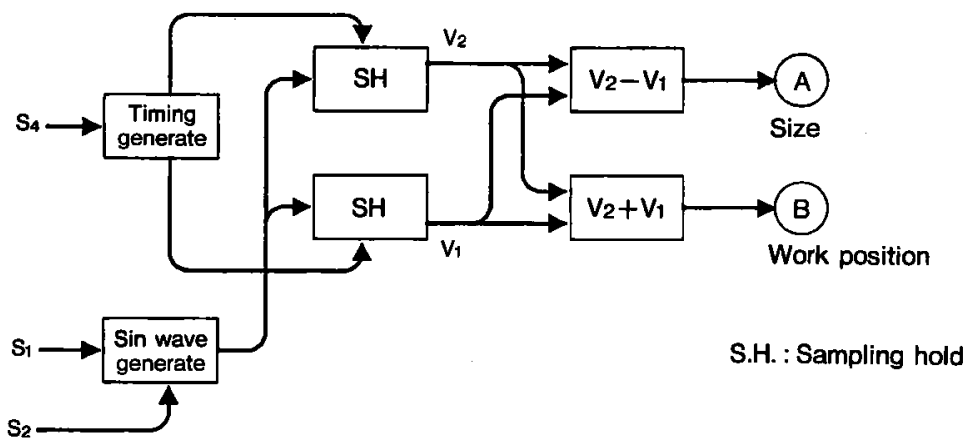

Fig. 3. Block diagram of size gauge device.

Table 2. Specifications of size gauge device.

\begin{tabular}{l|l}
\hline \multicolumn{1}{c|}{ Note } & \multicolumn{1}{c}{ Specifications } \\
\hline Measurable range & From $1 \mathrm{~mm}$ to $195 \mathrm{~mm}$ \\
Stability & $\pm 20 \mu \mathrm{m}$ \\
Lineality & $\pm 20 \mu \mathrm{m}$ \\
Measuring time & $1 \mathrm{~ms}$ \\
Number of data used for & $2,4,8,16,32,64,128$ or 256 \\
the mean value & He-Ne laser, 1mw \\
Illumination &
\end{tabular}

て判定合格で入庫する。

また，当ラインに䢘入した主な機器およびその性

能を Table 1 に示す。

2.2 寸法測定設備

\subsection{1 寸法測定器}

当 SRIC ラインで採用した寸法測定器はフンリ ッ製である。Fig. 2 に光学系の原理図を, Fig. 3 に 信号処理のブロック・ダイフグラムを，また Table 


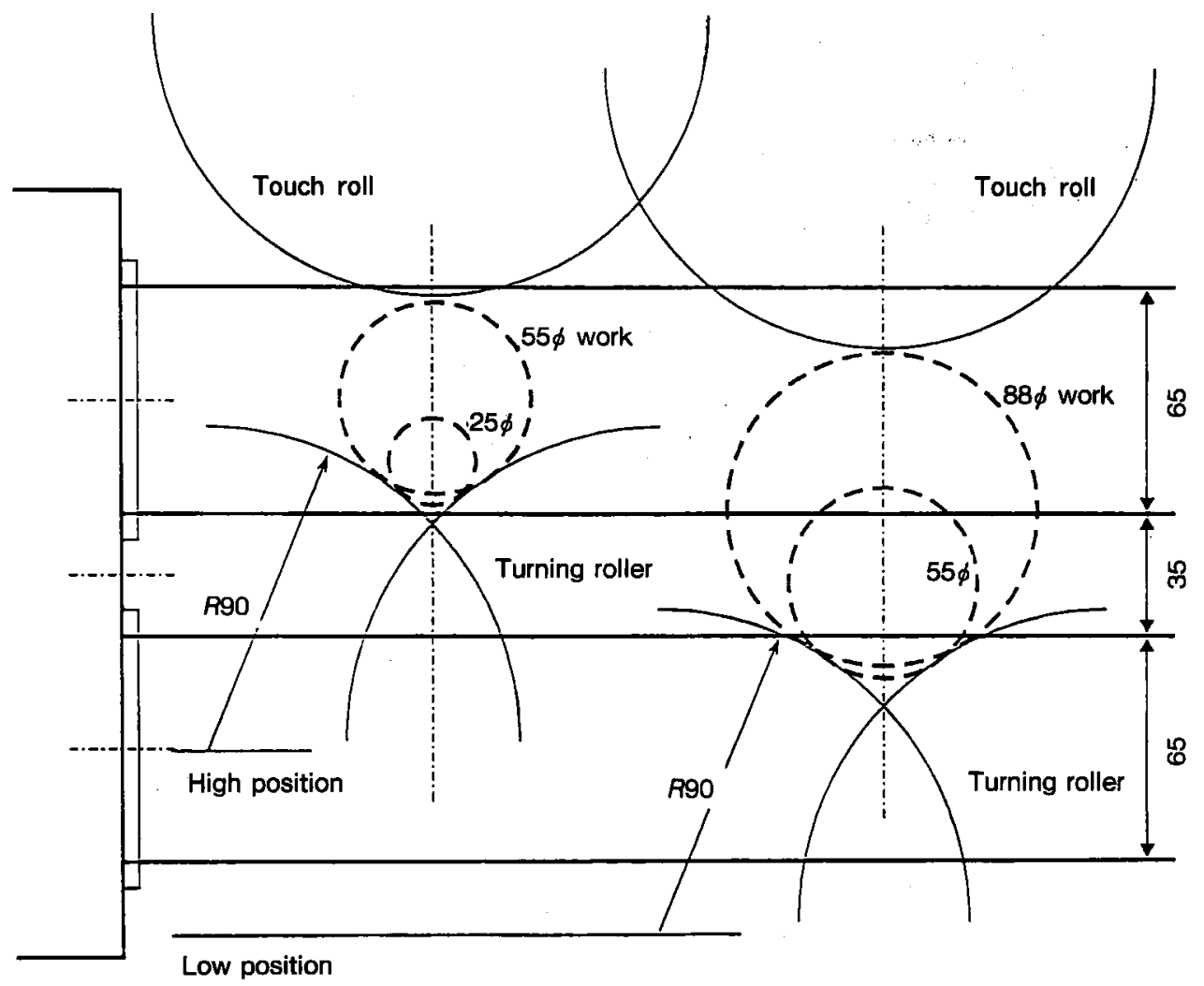

Fig. 4. Sensor position adjustment system.

2 に寸法測定器の主な仕様を示す。

\subsection{2 高さ調整設借}

当ラインで扱ら製品は $25 ８ 8 \mathrm{~mm}$ の丸棒鋼であ り，55mm 未満をシングルビーム，55mm 以上を ダブルビームで測定する。ダブルビームで測定す る場合はビームとビームの間に $35 \mathrm{~mm}$ の隙間があ るため，Fig.4 に示すようにビームの走査方向に 対して製品位置を変える必要がある。本設備では 製品の高さを上下させるのではなく寸法測定器の 検出部の高さを 2 段階に变化させる方法を採用し ている。すなわち，25～55mm の製品を測定する 時は High 位置で，55 88mm の製品を測定する 時はLow 位置に自動調整している。

\subsection{3 製品回転設備}

製品の外径怙よび端曲りを正しく測定するため に先端から300mm の位置を支点にして回転角速 度が一定となるように回転させるために直径 180 $\mathrm{mm}$ の回転ローラの上に製品を載せ，上からタッ
チロールで押さえるようにしている。また，回転 ローラ上の製品回転数を一定にするために VVVF制御 (Variable Voltage Variable Frequency）を採用している。

\section{3. 寸法測定システムの概要}

\section{1 ハードウェアの權成}

Fig. 5 にハードウェアの構成を示す。寸法測定 器の制御システムは当社高蔵製作所製のマイコン DAMIC-8を中心に構成されており，SRIC ライ ン制御用コンピュータ（以下 SRIC プロコンと称 す）さらに生産管理用ホストコンピュータ（以下 ホストと称す)と接続されている。

寸法測定マイコンはSRICプロコンと接続され て寸法測定規格を結束単位に通知され湘定結果を 返送する。また寸法測定器とは外径測定值につい てはRS-232C 無手順で端曲り測定値はフナログ 


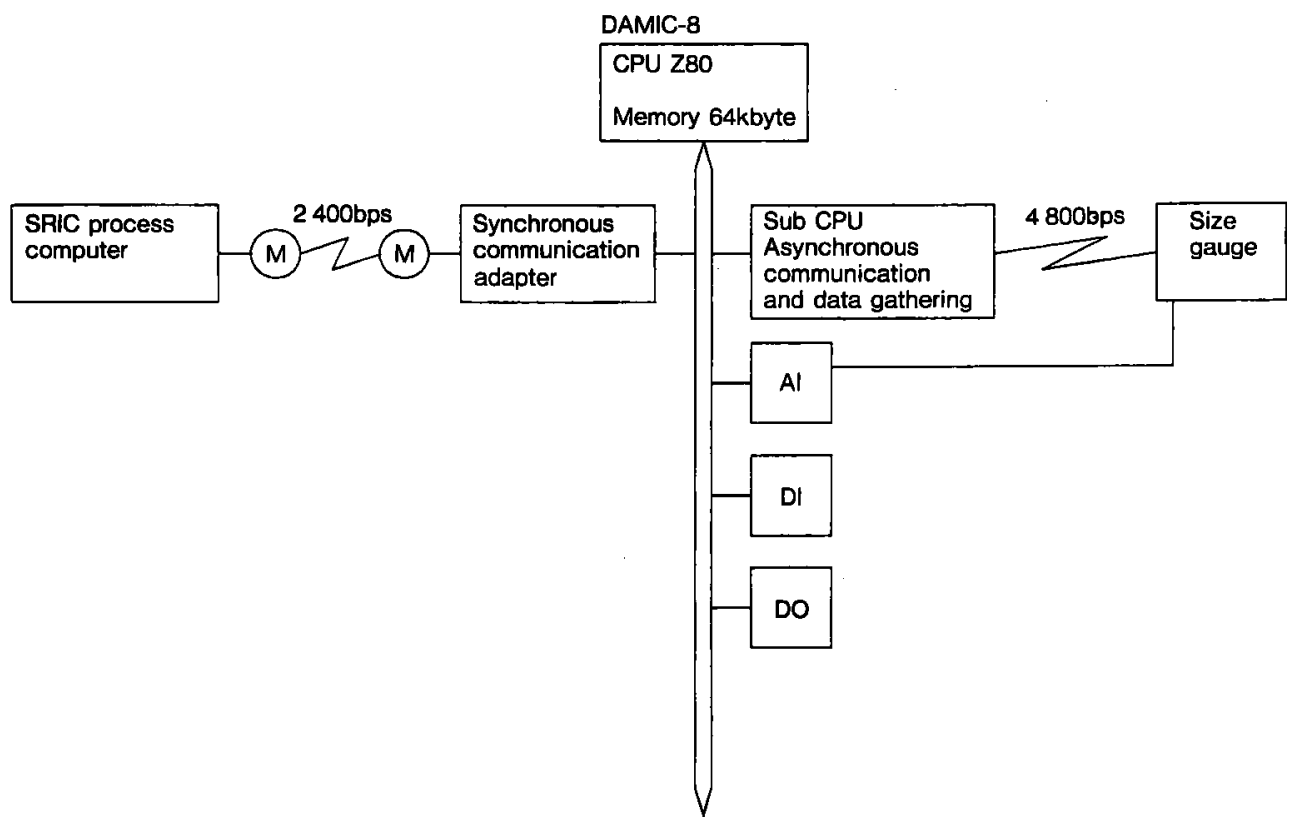

Fig. 5. Hardware construction of micro computer for profile inspection.

信号にて伝送される。

\section{2 ソフトゥェア概要}

SRICシステムは出荷検查作業で，現品の目視 検査および前工程での検査結果を合わせ最終判定 を行っており，この出検作業の負荷軽减のために ๖, 寸法測定結果の判定は, 異常材のみ作業者が 判断するようにシステムを設計した。

当システムの主な機能は以下のとらりである。

（1）外形寸法測定値の収集

（2）外径寸法測定のタイミング制御

（3）製品回転用ローラの回転数制御

（4） 寸法測定データの規格判定

(5) 端曲りデータの収集

（6）端曲りデータの規格判定

(7). 寸法測定器の検出器の高さ調整

(8) 判定結果の処置

(9) 作業者への通知

また，それらの機能の各コンピュータの分担を

Fig. 6 亿示す。

\section{4. システムの機能}

寸法湘定装置では，瞬時瞬時の外径寸法拉よび 材料位置を測定し, マイコンでその值を取り出す。
マイコンでは，製品 1 本につき 1 回転するらち に, 外径 8 箇所, 材料位置16筒所を測定し, 良否 を判定する。この1本ごとの良否判定を束単位に まとめて，プロコンへ伝送する。

プロコンでは, 束単位に判定を行い出荷検查作 業者へ通知する。むた, 束内での平均, 最大, 最 小，標準偏差を計算し品質管理情報として記録す る。

\section{1 SRIC プロコンの機能}

SRIC プロコンは当 SRIC ライン全体の制御を 行っているシステムで寸法測定システムとして は，以下の機能を分担している。

\subsection{1 高 さ調 整}

寸法測定器の検出器の高さをロット単位に規格 寸法をるとに自動調整している。

\subsection{2 回転ローラの回転数制御}

製品を回転角速度一定にするためにローラ回転 数を規格寸法ごとに計算し自動設定する。すなわ ち，ローラに直結しているモータの回転数を計算

し，モータ回転数制御を行う。

$d:$ 製品外径

$n:$ 製品回転数

$f:$ モータ回転数 


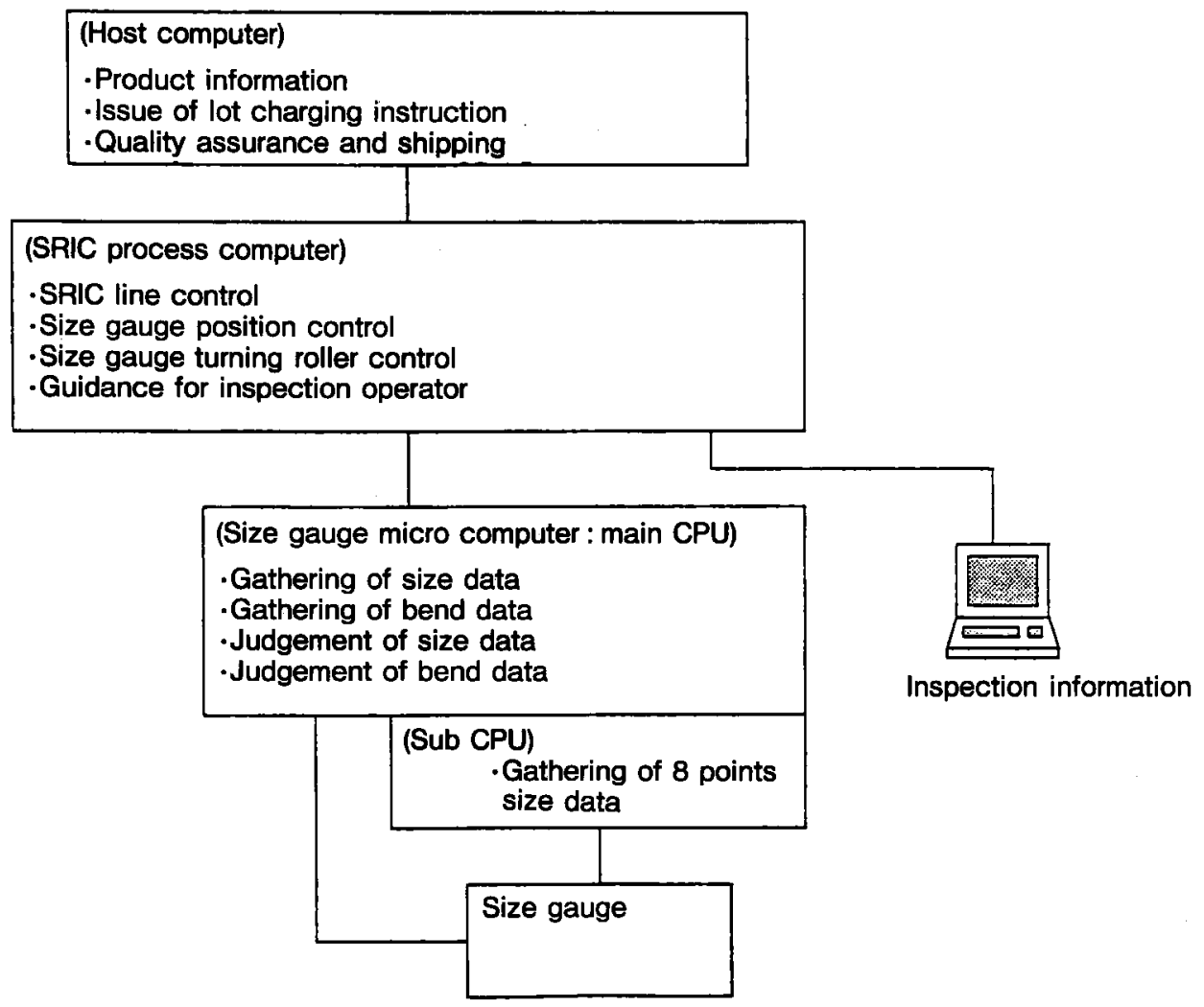

Fig. 6. Share of function.

$D:$-ラ外径

$\alpha:$ 減速比

とすると，ローラ周速 $V_{\mathrm{r}}$ は

$$
V_{\mathrm{r}}=\pi D \times \alpha f
$$

となり, 製品回転数 $n$ は

$$
n=(\pi D \times \alpha f) / \pi d
$$

となり，モータ回転数は

$$
f=(n / D \alpha) \times d
$$

となる。この計算式で $n$ が常に一定になるよう

モータ回転数 $f$ を制御する。

\subsection{3 寸法測定マイコン制御}

寸法測定マイコンに対して結束単位に製品本 数, 寸法規格, 偏径差規格, 端曲り規格を与え, その湘定結果を収集する。

\subsection{4 作業者への通知}

製品外径, 偏径差, 端曲りの判定結果を出荷検 查作業者通知し判断させる。作業者は異常材の 入っている束のみに着目し，マニュフルで再検査
を行う。その結果異常と判定した束は不合格とし て报い入車しない。

\subsection{5 判定結果の処置}

寸法測定結果の規格判定結果をりとに，不合格 材があれば入庫保留にするなど，現品情報を付加 する。

\section{2 寸法測定マイコンの機能}

\subsubsection{SRIC プロコンとの情報授受}

寸法測定マイコンはSRIC プロコンより結束単 位に本数および製品寸法規格と端曲り規格を受け 取り，繁品 1 本ごとの規格判定結果を結束単位に まとめて SRIC プロコンへ送信する。また品質解 析を可能にするため，製品全体の平均値・標準偏 差を計算し同時に SRICプロコンへ送信してい る。

\subsection{2 测定データ収集}

（1）外径寸法湘定值収集

寸法測定マイコンはメイン CPU, サ.ブ CPU の 
2 個の CPUを持ってょりクメイン CPUは製品検 知センサより製品が測定位置に来たことを検知し サブ CPUに対して测定開始を指示する。サブ CPUは64msごとに 8 回外径寸法データを寸法測 定器より収集する。これは断面を 8 等分した位置 の各々の外径に対応する。収集した 8 個のデータ は加工せずに， ィインCPU へ送り込む。

(2) 端曲りデータの収集

製品が測定位置に来たことを検知し，さらに製

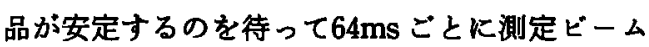
の走查方向に対する偏位量を16回収集する。すな わちこの偏位量の [最大一最小] の $1 / 2 か ゙$ 端曲り量 となる。

\subsection{3 寸法測定データ収集の規格判定}

サブ CPU で収集した 8 個の外径測定データを もとに寸法規格および偏径差規格の合否判定を行 5。

製品の寸法測定位置は，この8 個の外径から寸 法判定および偏径差判定を行う。

(1) 寸法判定

8 個の外埾全てが寸法公差範囲内であれば合格 とする。ところがこの時寸法測定位置に疪取り跡 がある場合，寸法は小さく測定され不合格と判定 される。この不合理をなくすために疵取り許容基 準(疪取り深さ XXmm 以下)があり，疵取り跡の 判断がつけば疪取り許容基準を適用しなければな らない。疵取り跡であるという判断は8 個の外径 測定結果の内, 寸法公差のマイナス側外れが連続 2 個以内ならば，これは症取り跡と判断している。

すなわち，寸法公差外れの場合は必ず連続 3 筒 所以上の寸法マイナスが発生することになる。寸 法判定は, この㾚取り跡を除いて寸法公差判定を 行う。しかし，疵取り跡の判断がまらがっている 可能性があるため, 㾟取り跡と判断した製品が 3 本連続で発生した場合は疵取り跡の判断がまらが っていた可能性があるので異常扱いとし，作業者 が実態を確認している。

(2) 偏径差判定

偏径差とは，当ラインで整備・検查する製品は， 丸棒鋼であるため，断面が真円であることが必要 であるが製造技術上の問題から，棈円になること がある。この真円度を測定し, 許容範囲判定を行 ら。

真円度判定は, [短径/長径]が $n$ \%以上ならば

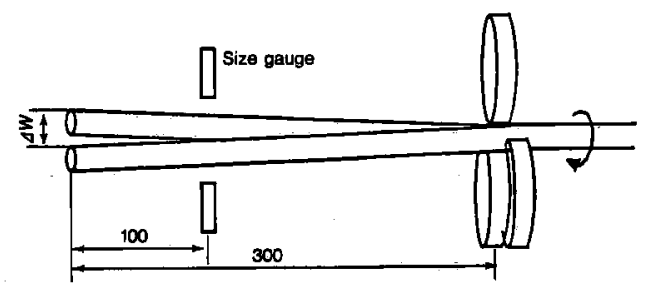

Fig. 7. Outline of bend measurement.

合格とするが，ここでは，この $n$ \%を [長径一短 径]の外径差に換算して判定を行う。

判定方法は， 8 個の外径寸法測定値のうち，疵 取り跡と判断したデータを除いた残りの外径を用 いて判定する。すなわち，データのらち [最大] と［最小]を選び出し，[最大一最小]を計算し， これが許容範囲に入っているか否かを判定する。

\subsection{4 端曲りデータの規格判定}

製品の外径測定のために，製品を回転させると きに，製品の端から $300 \mathrm{~mm}$ の位置をタッチ・ロー ルで押さえている。このため，製品に端曲りがあ ると，先端が振れる。この振れ幅を測定し， $1 / 2 し$ た值が端曲り量である。本設備では先端から100 $\mathrm{mm}$ の位置についている測定器からの被測定体中 心位置信号より,先端から $100 \mathrm{~mm}$ 部分の振れ幅を るとめ,この値から，先端の振れ幅を推定する。 端曲り測定方法は Fig. 7 に示すように,

$L \max$ ：中心位置偏位量の最大

$L \min$ : 中心位置偏位量の最小

$\Delta W 1 ：$ 測定点での曲り量

$\Delta W:$ 端曲り量

とすると, 測定点での曲り量 $\Delta W 1$ は

$\Delta W 1=(L \max -L \min ) / 2$

であり，端曲り量 $\Delta W$ は測定点の300/200倍であ るため,

$\Delta W=\Delta W 1 \times(300 / 200)$

この式に $\Delta W 1$ を代入すると，

$\Delta W=\{(L \max -L \min ) / 2\} \times(300 / 200)$

この式を整理すると，

$\Delta W=3 / 4(L \max -L \min )$

となる。 $\Delta W$ が端曲り規格よりる小さければ合格 とする。 


\section{5. 結}

当ラインでは，このよ5に，自動検査装置を十 分に活用し生産性の向上および品質保証精度の向 上を実証することができた。今後は，さらに整備 検查工程の生産性を向上させるため，同様な設備 を設置し，オフライン作業がなくなるようにして いくとともに，操業，技術開発など努力していく 所存である。
（文

献）

1）小沢；江川，稲葉：鉄と鋼, 69 (1983) 4, S182

2）小沢，中山，新貝：電気製鋼，55 (1984) 2, 93

3）小林, 山口, 佐々木, 小牧, 高井, 稲森：材 料とプロセス, 2 (1989) 5, 1559

4）那須田，中山：電気製鋼，61 (1990) 1, 55

5) アンリッ徃：レーザー応用計測機器, カタロ ク 